\title{
Fruit set and yield of pear cultivars as affected by reduced bee pollination period
}

\author{
Benedek, P. \& Varga, J. \\ University of West Hungary, Faculty of Agricultural Sciences, H-9201 Mosonmagyaróvár, 4 Vár, Hungary
}

\begin{abstract}
Summary: Results of our experiments prove that pear is more or less sensitive to the reduced bee pollination period. However, the reaction (or the sensitivity) of cultivars may be different to the reduced bee pollination. Most cultivars produce much less yield under reduced bee pollination or no yield with the exclusion of bees but in the case of some cultivars total exclusion of bees does not prevent the yield formation and what is more sometimes reduced bee pollination can be resulted in somewhat higher yield than open pollination. Typical reaction, however, is a significant yield reduction with reduced bee pollination. Pear seems to be somewhat less sensitive to the partial reduction of bee pollination period than apple or quince. The first half of the flowering period seems to be more important in yield formation because usually higher yield was resulted when pear cultivars received open pollination in the first than in the second half of the blooming period. Based on our experimental results no definite relationship between parthenocarpic capacity of cultivars and the yield under reduced bee pollination can be established. So reduced bee pollination does not seem to contribute the parthenocarpic fruit formation in pear.
\end{abstract}

Key words: pear, cultivars, reduced bee pollination, fruit set, yield, parthenocarpy

\section{Introduction}

It is evidence that bee pollination is vitally important in pear pollination and no commercial yield can be expected in lack of the contribution of bees as pollen vectors (Free 1993). However, weather can greatly influence bee activity at blooming fruit plantations and this affects the fruit set and yield because unfavourable weather can greatly reduce the effective pollination period. The unfavourable effect of reduced bee pollination has been demonstrated for a number of temperate zone fruit species (Benedek et al., 1989, 2000ab, Benedek \& Nyéki 1995, 1996a, 1996b, 1997; Rovertsi \& Unghini 1986). In the case of self-sterile fruit species and cultivars even partial reduction that is partial limitation of the effective duration of bee pollination period significantly reduces the fruit set and the yield. On the other hand, at self-fertile fruits, the effect of partial limitation of bee pollination period is usually small, but complete (or incomplete but strong) limitation usually results in a strong reduction of yield (Benedek \& Nyéki, 1995, 1996a). This means that not only self-sterile but also self-fertile fruits clearly depend on insect (bee) pollination (Benedek et al., 2000a).

Among temperate zone fruit species parthenocarpic fruit formation is relatively frequent in pear (Nyéki \& Soltész 1996, Nyéki et al., 1998) and it can influence its yield under poor pollination conditions. Consequently, pear can produce acceptable yield even under adverse conditions. In spite of this fact most studies on the effect of reduced bee pollination to the fruit set and the yield has been made with apple
(Benedek et al., 1989, Benedek \& Nyéki 1995, 1996a, 1996b, 1997, Benedek et al. 2000ab) and very little information was available to pear in this respect (Benedek \& Nyéki 1996a, Benedek et al. 2000a). It was established by Nyéki et al. (1998) that the inclination or capacity to parthenocarpy can be more or less different among cultivars but it is also largely dependent on site and season. Accordingly, some differences could be expected in the reaction of pear cultivars to reduced bee pollination and so we decided to carry out experiments to explore possible differences among them.

\section{Material and methods}

Experiments were carried out at two sites in the Small Hungarian Plain, at Győr in 2007 and at Mosonmagyaróvár in 2008 .

A commercial pear plantation was used in 2007 at Györ with some 9-10 years old trees planted 4 metres apart in $5 \mathrm{~m}$ wide rows. Experimental apiary was placed close to the orchard for pollination services. Three cultivars were involved in this orchard. Each treatment was applied at four distances from the apiary at two trees at each distance. Branches with some 30-50 flowers at the middle section of the crown were selected on the Southern and the Northern side of the crown at each experimental tree. Accordingly each treatment was repeated 16 times at each of the 3 cultivars involved.

At Mosonmagyaróvár a small experimental orchard was used that was surrounded with gardens of family houses. 
Some small hobby apiaries were in operation in the nearby. Dwarf trees were planted $3 \mathrm{~m}$ apart in $4 \mathrm{~m}$ rows. We used 10 cultivars for experimental purposes. Two trees were selected for each cultivar and two branches bearing some 30-40 flowers each were selected fort the treatments at the Southern and the Northern side of the crown. So each treatment was repeated 4 times altogether.

The inclination to parthenocarpy is known at most (10) of the 13 cultivars tested because those have been classified by Nyéki et al. (1998) into six categories that they have established as follows:

- Category 1: no tendency to pathenocarpous fruit set $(0 \%)$ :

Beurrée Hardy, Piroska, Mézes körte

- Category 2: very weak tendency to pathenocarpous fruit set $(0.1-1 \%)$ :

Bartlett (Vilmos)

- Category 3: weak tendency to pathenocarpous fruit set $(1.1-5 \%)$ :
Peckham's triumph, Beurée Bosc, Szücsi körte, Olivier de Serres

- Category 5: strong expression of parthenocarpy (10.1-20\%):

Clapp's favourite

- No information on capacity to parthenocarpy: Hóka, Téli esperes, Nemes krasszán

Treatments were applied at both experimental sites as follows: (1) $100 \%$ open = free pollination, no caging, (2) $67 \%$ open first $=$ open during the first $2 / 3$ of the flowering and caged for the last $1 / 3$ with bags of parchment paper, (3) $67 \%$ open last $=$ caged in the first $1 / 3$ of the flowering with bags of parchment paper and left open afterwards, (4) $50 \%$ open first $=$ free pollination in the first half of the flowering and caged afterwards with bags of parchment paper, (5) $50 \%$ open second $=$ caged at the first half of the blooming with bags of parchment paper and free pollination afterwards, (6) 33\% open first $=$ open for the first $1 / 3$ of flowering and caged afterwards

Table 1. Weather conditions in he flowering period of pear

\begin{tabular}{|c|c|c|c|c|c|c|}
\hline \multirow[b]{2}{*}{ Date } & \multicolumn{3}{|c|}{ in $2007 *$ (flowering period of pear: $8-24$ April) } & \multicolumn{3}{|c|}{ in 2008* (flowering period of pear: 13 - 30 April) } \\
\hline & $\begin{array}{l}\text { Precipitation } \\
\quad(\mathbf{m m})\end{array}$ & $\begin{array}{c}\text { Daily min. } \\
\text { temperature }\left({ }^{\circ} \mathrm{C}\right)\end{array}$ & $\begin{array}{c}\text { Daily max. } \\
\text { temperature }\left({ }^{\circ} \mathbf{C}\right)\end{array}$ & $\begin{array}{c}\text { Precipitation } \\
(\mathbf{m m})\end{array}$ & $\begin{array}{c}\text { Daily min. } \\
\text { temperature }\left({ }^{\circ} \mathrm{C}\right)\end{array}$ & $\begin{array}{c}\text { Daily max. } \\
\text { temperature }\left({ }^{\circ} \mathbf{C}\right)\end{array}$ \\
\hline 1 April & - & 2.8 & 18.0 & - & 2.6 & 18.1 \\
\hline 2 April & - & 2.1 & 17.7 & 1.1 & 5.1 & 14.4 \\
\hline 3 April & - & 0.9 & 18.4 & $<0.1 \mathrm{~mm}$ & 2.9 & 12.4 \\
\hline 4 April & - & 2.4 & 13.9 & - & 3.9 & 12.8 \\
\hline 5 April & - & -0.6 & 14.2 & - & 2.7 & 13.3 \\
\hline 6 April & - & 7.9 & 19.1 & - & -0.2 & 16.5 \\
\hline 7 April & - & 4.3 & 17.3 & 4.4 & 3.7 & 9.2 \\
\hline 8 April & - & 3.8 & 16.4 & - & 3.0 & 10.7 \\
\hline 9 April & - & 2.2 & 19.5 & - & 4.6 & 20.4 \\
\hline 10 April & - & 5.7 & 20.6 & - & 10.5 & 22.1 \\
\hline 11 April & - & 7.5 & 18.9 & 0.1 & 13.3 & 22.9 \\
\hline 12 April & - & 6.0 & 22.4 & - & 5.6 & 16.1 \\
\hline 13 April & - & 5.4 & 24.0 & - & 3.5 & 18.0 \\
\hline 14 April & - & 6.7 & 23.7 & - & 4.7 & 18.9 \\
\hline 15 April & - & 5.0 & 23.4 & 0.9 & 6.0 & 13.9 \\
\hline 16 April & - & 5.9 & 19.7 & 0.2 & 3.3 & 10.4 \\
\hline 17 April & - & 6.3 & 23.1 & 0.8 & 0.6 & 13.1 \\
\hline 18 April & $<0.1 \mathrm{~mm}$ & 6.2 & 16.3 & - & 1.8 & 19.0 \\
\hline 19 April & - & 2.9 & 16.5 & 0.3 & 10.7 & 20.4 \\
\hline 20 April & - & 4.6 & 19.7 & - & 7.0 & 19.9 \\
\hline 21 April & - & 3.8 & 16.0 & 20.5 & 8.2 & 23.3 \\
\hline 22 April & - & 1.5 & 18.6 & - & 8.4 & 20.2 \\
\hline 23 April & - & 3.4 & 23.9 & - & 7.4 & 13.2 \\
\hline 24 April & - & 6.1 & 23.0 & - & 3.1 & 17.5 \\
\hline 25 April & - & 9.5 & 21.5 & 1.3 & 3.7 & 17.1 \\
\hline 26 April & - & 7.6 & 24.2 & $<0.1 \mathrm{~mm}$ & 7.1 & 18.5 \\
\hline 27 April & - & 6.8 & 24.6 & - & 5.9 & 20.2 \\
\hline 28 April & - & 6.2 & 25.6 & - & 4.3 & 24.1 \\
\hline 29 April & - & 7.2 & 22.3 & $<0.1 \mathrm{~mm}$ & 8.1 & 20.9 \\
\hline 30 April & - & 3.6 & 17.9 & - & 10.5 & 19.8 \\
\hline
\end{tabular}

*Note: figures in the flowering period of pear are in a frame in Arial bold 
with bags of parchment paper, (7) $0 \%$ open = caged with bags of parchment paper during the whole blooming period.

Measurements were made after petal fall and at harvest time. Primary fruit set after petal fall and yield at harvest time (number of fruits and the total mass of the harvested fruits) was registered at each branch. All measurements were corrected for 50 flowers because the number of flowers on the experimental branches varied. Corrected figures were used in the analyses.

Weather conditions were registered during the blooming period of pear because of some possible strong effect on bee activity (Table 1.). Flowering period lasted from the $8^{\text {th }}$ till the $22^{\text {nd }}$ of April in 2007 and from the $13^{\text {th }}$ till the $30^{\text {th }}$ of April in 2008.

In the year of 2007 weather was fairly warm and sunny during the flowering period of pear and so it failed to prevent bee activity (Table 1). There was practically no rain all along. Daytime temperatures varied between $16-20{ }^{\circ} \mathrm{C}$ in both the first $1 / 3$ and the last $1 / 3$ and it ranged between $19-24{ }^{\circ} \mathrm{C}$ in the middle part of the blooming period.

In the next year, in 2008 the weather was slightly more changeable in April (Table 1). There were 8 days of the total 18 with some light rain showing that cloudy weather was more frequent than in the previous year. In the first $1 / 3$ of the flowering daytime temperatures ranged between 10 to $19{ }^{\circ} \mathrm{C}$ with 3 days of some precipitation. The last $1 / 3$ was warmer with daytime temperatures ranging from 17 to $24{ }^{\circ} \mathrm{C}$. The first half of the flowering period was somewhat less favourable to bees (daytime temperatures from 10 to $23{ }^{\circ} \mathrm{C}$ and 5 days with some slight rain) than the second half of that (daytime temperatures from 13 till 24 and less rainy days).

\section{Results}

Results are demonstrated in Table 1. Primary fruit set was more or less decreasing with the increasing reduction of bee pollination period. However, in the case of some cultivars very little decrease was detected in the primary set with the decreasing bee pollination period (Beurrée Bosc, Beurée Hardy). At some instances more or less higher primary set values were detected at more restricted than at less reduced bee pollination. Deviations like this were usually small but the same were rather large at some other instances. Thus the primary set values were not truly reliable measurements on the effect of reduced bee pollination because sometimes fairly high set values were detected even under greatly reduced bee pollination.

Number of fruits at harvest and mass of harvested fruit were more reliable measurements than the primary set (Table 1). All tested cultivars reacted to the exclusion of bees with decreasing yield because most of them produced no yields (Beurrée Bosc, Szücsi körte, Clapp's favourite, Mézes körte, Olivier de Serres, Nemes krasszán) or much less yield (Peckham's triumph, Beurée Hardy) than at less reduced or at open pollination. However, two of the tested cultivars produced fairly good yield when no bees were present on branches caged all along the flowering period (Hóka, Téli esperes). Moderate reduction of bee pollination (67\% open) sometimes was resulted in more yield than open pollination (Beurrée Bosc, Mézes körte, Nemes krasszán). At two instances (Hóka, Beurée Hardy) yield was higher at 50\% reduction than at open pollination $(100 \%)$ and at moderate reduction (67\%). These figures are well expressed also by the relative yield of cultivars as illustrated in Table 2 where the mean of all yield data from different treatments related to a given cultivar was used as a basis value $(100 \%)$ and all individual yield values at the give cultivar were divided with this figure and were expressed as the relative percentage of that.

Data on relative yields from Table 2 were used to count relationship between the effective pollination period and the yield of pear cultivars. To these calculations, we used the stock of data separately from the Györ experiment (2007) and from the Mosonmagyaróvár experiment (2008) and afterwards from both experiments together (Györ $2007+$ Mosonmagyaróvár 2008). The correlation between the effective bee pollination period and the relative yield of pear cultivars was highly significant at each case (Table 3) at a probability level of $95 \%$. The equation calculated with all experimental results altogether showed definite linear regression between the effective pollination period and the yield (Fig 1).

Above results show that different cultivars have given slightly different reaction to reduced bee pollination (Table 2). Namely, as expected, more than half of them produced much less yield under reduced bee pollination or no yield with the exclusion of bees (Beurrée Bosc, Szücsi körte, Clapp's favourite, Mézes körte, Olivier de Serres, Nemes krasszán). In the case of some other cultivars, on the other hand, total exclusion of bees has fail to inhibit yield formation (Hóka, Téli esperes), and what is more sometimes reduced bee pollination has resulted in somewhat higher yield than open pollination (Beurrée Bosc, Mézes körte, Nemes krasszán, Hóka, Beurée Hardy). It is notable that 50\% reduction of bee pollination period was resulted in different amount of yield when bees were excluded in the first than in the second half of the flowering period. Majority of the cultivars (with only two exceptions) produced more yield when they received bee pollination in first half of the flowering period than in the case when open pollination was received in the second half of the blooming (Table 2).

Taking the parthenocarpic capacity of cultivars into account no definite relationship between the yield and this feature can be established. Clapp's favourite for example that was classified with strong expression of parthenocarpy by Nyéki, Soltész and Iváncsics (1998) - strongly reacted to the reduction of the bee pollination period and gave no yield with the complete exclusion of bees (Tables 1 and 2). The cultivar Piroska, on the other hand, classified as having no tendency to pathenocarpous fruit set (Nyéki, Soltész and Iváncsics 1998) produced fairly acceptable yield even under complete reduction of bee pollination (Table2). The cultivars belonging to the category with weak tendency to 
Table 2. Fruit set and yield of pear cultivars as affected by reduced bee pollination period

\begin{tabular}{|c|c|c|c|c|c|c|c|c|}
\hline \multirow[b]{2}{*}{ Cultivar } & \multirow[b]{2}{*}{$\begin{array}{l}\text { Fruit set } \\
\text { and yield from } \\
\mathbf{5 0} \text { flowers }\end{array}$} & \multicolumn{7}{|c|}{ Treatments: effective pollination period $(\%)$ during the flowering of pear trees } \\
\hline & & $\begin{array}{l}\text { 100\% open } \\
\text { (free } \\
\text { pollination) }\end{array}$ & $\begin{array}{c}\text { 67\% open } \\
\text { first (caged } \\
\text { in the last } \\
1 / 3 \text { of the } \\
\text { flowering) }\end{array}$ & $\begin{array}{c}\text { 67\% open } \\
\text { last (caged } \\
\text { in the first } \\
1 / 3 \text { of the } \\
\text { flowering) } \\
\text { flowering) }\end{array}$ & \begin{tabular}{|c|}
$\mathbf{5 0 \%}$ open \\
first (caged \\
in the \\
second \\
half of the \\
flowering*) \\
\end{tabular} & $\begin{array}{l}\text { 50\% open } \\
\text { second } \\
\text { (caged in } \\
\text { the first half } \\
\text { of the }\end{array}$ & $\begin{array}{c}\text { 33\% open } \\
\text { first (open } \\
\text { in the first } \\
1 / 3 \text { of the } \\
\text { flowering) }\end{array}$ & $\begin{array}{l}\text { 0\% open } \\
\text { (caged during } \\
\text { the whole } \\
\text { flowering } \\
\text { period) }\end{array}$ \\
\hline \multicolumn{9}{|c|}{ Györ 2007: mean and standard error ( $n$ = 16 for each mean value) } \\
\hline \multirow{3}{*}{$\begin{array}{l}\text { Peckham' } \\
\text { s triumph }\end{array}$} & $\begin{array}{l}\text { primary fruit set }(\%) \\
\text { after petal fall }\end{array}$ & $25.8 \pm 2.4$ & $18.6 \pm 3.3$ & $19.7 \pm 1.7$ & $14.8 \pm 2.3$ & $20.5 \pm 3.3$ & $12.2 \pm 2.2$ & $6.4 \pm 1.4$ \\
\hline & number of fruits at harvest time & $1.8 \pm 0.5$ & $1.3 \pm 0.7$ & $0.7 \pm 0.2$ & $0.6 \pm 0.4$ & $0.2 \pm 0.1$ & $0.8 \pm 0.4$ & $0.1 \pm 0.1$ \\
\hline & $\begin{array}{l}\text { mass of fruits (yield) from } \\
50 \text { flowers }(\mathrm{g})\end{array}$ & $223.9 \pm 59.3$ & $164.5 \pm 90.8$ & $85.9 \pm 24.4$ & $63.5 \pm 43.7$ & $24.2 \pm 16.9$ & $92.6 \pm 43.5$ & $10.6 \pm 10.6$ \\
\hline \multirow{3}{*}{ Beurrée Bosc } & $\begin{array}{l}\text { primary fruit set }(\%) \\
\text { after petal fall }\end{array}$ & $43.3 \pm 2.5$ & $43.4 \pm 1.6$ & $44.4 \pm 1.6$ & $38.9 \pm 3.2$ & $47.7 \pm 1.4$ & $40.1 \pm 2.1$ & $33.3 \pm 3.7$ \\
\hline & number of fruits at harvest time & $0.9 \pm 0.3$ & $1.7 \pm 1.1$ & $0.8 \pm 0.5$ & 0 & 0 & $0.6 \pm 0.4$ & 0 \\
\hline & $\begin{array}{l}\text { mass of fruits (yield) from } \\
50 \text { flowers }(\mathrm{g})\end{array}$ & $156.9 \pm 48.9$ & $279.2 \pm 183.8$ & $138.4 \pm 81.5$ & 0 & 0 & $90.4 \pm 65.3$ & 0 \\
\hline \multirow{3}{*}{$\begin{array}{l}\text { Bartlett } \\
\text { (Vilmos) }\end{array}$} & $\begin{array}{l}\text { primary fruit set (\%) after } \\
\text { petal fall }\end{array}$ & $41.7 \pm 1.6$ & $16.6 \pm 2.2$ & $32.5 \pm 3.4$ & $27.7 \pm 3.5$ & $24.4 \pm 3.7$ & $27.1 \pm 3.8$ & $17.2 \pm 3.9$ \\
\hline & number of fruits at harvest time & $1.2 \pm 0.3$ & $0.3 \pm 0.3$ & $0.4 \pm 0.2$ & $0.8 \pm 0.5$ & $0.1 \pm 0.1$ & $0.4 \pm 0.2$ & 0 \\
\hline & $\begin{array}{l}\text { mass of fruits (yield) from } \\
50 \text { flowers }(\mathrm{g})\end{array}$ & $135.4 \pm 34.7$ & $27.4 \pm 27.4$ & $31.4 \pm 17.7$ & $97.4 \pm 67.9$ & $13.2 \pm 9.1$ & $58.9 \pm 35.9$ & 0 \\
\hline \multicolumn{9}{|c|}{ Mosonmagyaróvár 2008: mean and standard error $(n=4$ for each mean value) } \\
\hline \multirow{3}{*}{ Hóka } & $\begin{array}{l}\text { primary fruit set }(\%) \text { after } \\
\text { petal fall }\end{array}$ & $28.8 \pm 1.7$ & $13.1 \pm 6.1$ & $29.1 \pm 4.9$ & $19.25 \pm 7.7$ & $19.0 \pm 7.0$ & $16.7 \pm 2.7$ & $14.5 \pm 6.2$ \\
\hline & number of fruits at harvest time & $8.7 \pm 3.2$ & $1.4 \pm 1.4$ & $7.0 \pm 3.1$ & $9.4 \pm 5.7$ & $3.1 \pm 2.3$ & $2.5 \pm 2.5$ & $3.0 \pm 2.4$ \\
\hline & $\begin{array}{l}\text { mass of fruits (yield) from } \\
50 \text { flowers }(\mathrm{g})\end{array}$ & $770.0 \pm 326.5$ & $84.4 \pm 84.4$ & $483.1 \pm 282.1$ & $1034.9 \pm 678.0$ & $248.0 \pm 182.6$ & $247.5 \pm 247.5$ & $264.3 \pm 223.9$ \\
\hline \multirow{3}{*}{ Beurrée Hardy } & $\begin{array}{l}\text { primary fruit set }(\%) \text { after } \\
\text { petal fall }\end{array}$ & $23.5 \pm 4.1$ & $26.3 \pm 3.5$ & $19.5 \pm 2.2$ & $20.1 \pm 1.6$ & $18.4 \pm 5.5$ & $20.6 \pm 0.9$ & $12.7 \pm 5.2$ \\
\hline & number of fruits at harvest time & $8.3 \pm 3.6$ & $0.6 \pm 0.6$ & $2.7 \pm 1.1$ & $3.8 \pm 1.3$ & 0 & $4.1 \pm 0.6$ & $07 . \pm 0.7$ \\
\hline & $\begin{array}{l}\text { mass of fruits (yield) from } \\
50 \text { flowers }(\mathrm{g})\end{array}$ & $1459.3 \pm 634.8$ & $67.5 \pm 67.5$ & $346.1 \pm 156.6$ & $555.2 \pm 190.5$ & 0 & $581.2 \pm 52.6$ & $112.5 \pm 112.5$ \\
\hline \multirow{3}{*}{$\begin{array}{l}\text { Peckham's } \\
\text { triumph }\end{array}$} & $\begin{array}{l}\text { primary fruit set }(\%) \text { after } \\
\text { petal fall }\end{array}$ & $26.6 \pm 3.9$ & $26.3 \pm 9.0$ & $31.1 \pm 3.9$ & $34.3 \pm 8.1$ & $21.5 \pm 2.4$ & $20.3 \pm 7.5$ & $16.5 \pm 3$ \\
\hline & number of fruits at harvest time & $2.3 \pm 0.4$ & $3.6 \pm 2.0$ & $4.0 \pm 1.9$ & $6.1 \pm 4.0$ & $0.6 \pm 0.6$ & $2.5 \pm 1.5$ & $1.2 \pm 0.8$ \\
\hline & $\begin{array}{l}\text { mass of fruits (yield) from } \\
50 \text { flowers }(\mathrm{g})\end{array}$ & $196.1 \pm 49.0$ & $220.1 \pm 139.1$ & $310.9 \pm 81.7$ & $880.9 \pm 508.9$ & $36.9 \pm 39.6$ & $244.9 \pm 147.9$ & $76.8 \pm 50.0$ \\
\hline \multirow{3}{*}{ Téli esperes } & $\begin{array}{l}\text { primary fruit set }(\%) \text { after } \\
\text { petal fall }\end{array}$ & $23.3 \pm 4.9$ & $18.9 \pm 7.5$ & $9.5 \pm 2.3$ & $12.4 \pm 3.0$ & $14.2 \pm 6.0$ & $11.6 \pm 5.2$ & $14.8 \pm 2.9$ \\
\hline & number of fruits at harvest time & $2.0 \pm 1.2$ & $0.7 \pm .7$ & $0.5 \pm 0.5$ & $0.6 \pm 0.6$ & $0.34 \pm 0.34$ & 0 & $0.3 \pm 0.3$ \\
\hline & $\begin{array}{l}\text { mass of fruits (yield) from } \\
50 \text { flowers }(\mathrm{g})\end{array}$ & $241.5 \pm 139.9$ & $97.8 \pm 98.8$ & $57.5 \pm 57.5$ & $85.1 \pm 85.1$ & $41.5 \pm 41.6$ & 0 & $53.3 \pm 53.3$ \\
\hline \multirow{3}{*}{ Piroska } & $\begin{array}{l}\text { primary fruit set (\%) after } \\
\text { petal fall }\end{array}$ & $27.9 \pm 5.4$ & $14.7 \pm 8.9$ & $13.1 \pm 4.3$ & $22.5 \pm 1.5$ & $8.0 \pm 2.9$ & $4.7 \pm 2.4$ & $4.7 \pm 1.7$ \\
\hline & number of fruits at harvest time & $1.9 \pm 0.8$ & $0.3 \pm 0.3$ & $1.0 \pm 1.0$ & 0 & $1.4 \pm 0.8$ & $1.2 \pm 1.2$ & $0.5 \pm 0.5$ \\
\hline & $\begin{array}{l}\text { mass of fruits (yield) from } \\
50 \text { flowers }(\mathrm{g})\end{array}$ & $93.4 \pm 39.6$ & $17.1 \pm 17.1$ & $52.0 \pm 52.0$ & 0 & $70.3 \pm 41.0$ & $52.0 \pm 52.0$ & $28.8 \pm 28.8$ \\
\hline \multirow{3}{*}{ Szücsi körte } & $\begin{array}{l}\text { primary fruit set }(\%) \text { after } \\
\text { petal fall }\end{array}$ & $7.9 \pm 1.7$ & $5.9 \pm 1.0$ & $5.0 \pm 1.9$ & $2.5 \pm 1.3$ & $5.8 \pm 3.1$ & $5.5 \pm 2.4$ & $2.5 \pm 2.51$ \\
\hline & number of fruits at harvest time & $0.5 \pm 0.3$ & $0.6 \pm 0.6$ & 0 & 0 & $0.7 \pm 0.7$ & $0.7 \pm 0.7$ & 0 \\
\hline & $\begin{array}{l}\text { mass of fruits (yield) from } \\
50 \text { flowers }(\mathrm{g})\end{array}$ & $68.9 \pm 43.3$ & $72.7 \pm 72.5$ & 0 & 0 & $50.0 \pm 50.0$ & $62.5 \pm 62.5$ & 0 \\
\hline \multirow{3}{*}{$\begin{array}{l}\text { Clapp's } \\
\text { favourite }\end{array}$} & $\begin{array}{l}\text { primary fruit set }(\%) \text { after } \\
\text { petal fall }\end{array}$ & $22.6 \pm 2.3$ & $18.8 \pm 3.6$ & $21.1 \pm 3.1$ & $12.3 \pm 5.3$ & $9.8 \pm 2.5$ & $11.5 \pm 4.7$ & $9.2 \pm 2.1$ \\
\hline & number of fruits at harvest time & $5.2 \pm 1.7$ & $2.1 \pm 1.4$ & $5.1 \pm 2.3$ & $1.7 \pm 1.7$ & $1.5 \pm 0.9$ & $1.3 \pm 1.3$ & 0 \\
\hline & $\begin{array}{l}\text { mass of fruits (yield) from } \\
50 \text { flowers }(\mathrm{g})\end{array}$ & $447.8 \pm 147.4$ & $189.3 \pm 125.9$ & $408.2 \pm 76.7$ & $165.4 \pm 165.4$ & $128.8 \pm 82.8$ & $80.3 \pm 80.3$ & 0 \\
\hline \multirow{3}{*}{ Mézes körte } & $\begin{array}{l}\text { primary fruit set (\%) after } \\
\text { petal fall }\end{array}$ & $15.5 \pm 3.4$ & $5.7 \pm 5.7$ & $11.4 \pm 4.2$ & $9.7 \pm 5.2$ & $7.8 \pm 2.0$ & $4.3 \pm 1.7$ & $0.3 \pm 0.3$ \\
\hline & number of fruits at harvest time & $0.6 \pm 0.6$ & $1.1 \pm 1.1$ & $1.0 \pm 1.0$ & $1.0 \pm 1.0$ & $0.3 \pm 0.3$ & 0 & 0 \\
\hline & $\begin{array}{l}\text { mass of fruit (yield) from } \\
50 \text { flowers }(\mathrm{g})\end{array}$ & $24.3 \pm 17.6$ & $42.1 \pm 43.1$ & $43.6 \pm 43.6$ & $23.1 \pm 23.1$ & $9.9 \pm 9.9$ & 0 & 0 \\
\hline
\end{tabular}




\begin{tabular}{|c|c|c|c|c|c|c|c|c|}
\hline \multirow[b]{2}{*}{ Cultivar } & \multirow[b]{2}{*}{$\begin{array}{c}\text { Fruit set } \\
\text { and yield from } \\
50 \text { flowers }\end{array}$} & \multicolumn{7}{|c|}{ Treatments: effective pollination period (\%) during the flowering of pear trees } \\
\hline & & $\begin{array}{l}\text { 100\% open } \\
\text { (free } \\
\text { pollination) }\end{array}$ & $\begin{array}{l}\text { 67\% open } \\
\text { first (caged } \\
\text { in the last } \\
1 / 3 \text { of the } \\
\text { flowering) }\end{array}$ & $\begin{array}{l}\text { 67\% open } \\
\text { last (caged } \\
\text { in the first } \\
1 / 3 \text { of the } \\
\text { flowering) } \\
\text { flowering) }\end{array}$ & $\begin{array}{l}\text { 50\% open } \\
\text { first (caged } \\
\text { in the } \\
\text { second } \\
\text { half of the } \\
\text { flowering*) }\end{array}$ & $\begin{array}{l}\text { 50\% open } \\
\text { second } \\
\text { (caged in } \\
\text { the first half } \\
\text { of the }\end{array}$ & $\begin{array}{l}33 \% \text { open } \\
\text { first (open } \\
\text { in the first } \\
1 / 3 \text { of the } \\
\text { flowering) }\end{array}$ & $\begin{array}{l}\text { 0\% open } \\
\text { (caged during } \\
\text { the whole } \\
\text { flowering } \\
\text { period) }\end{array}$ \\
\hline \multirow{3}{*}{$\begin{array}{l}\text { Seres } \\
\text { Olivier }\end{array}$} & $\begin{array}{l}\text { primary fruit set (\%) after } \\
\text { petal fall }\end{array}$ & $10.7 \pm 2.6$ & $15.2 \pm 2.9$ & $19.7 \pm 1.9$ & $14.0 \pm 4.0$ & $7.0 \pm 2.6$ & $6.9 \pm 3.5$ & $4.1 \pm 1.9$ \\
\hline & number of fruits at harvest time & $0.7 \pm 0.7$ & $0.4 \pm 0.5$ & $0.8 \pm 0.5$ & 0 & 0 & 0 & 0 \\
\hline & $\begin{array}{l}\text { mass of fruits (yield) from } \\
50 \text { flowers }(\mathrm{g})\end{array}$ & $91.0 \pm 91.0$ & $52.8 \pm 52.8$ & $105.9 \pm 79.6$ & 0 & 0 & 0 & 0 \\
\hline \multirow{3}{*}{$\begin{array}{l}\text { Nemes } \\
\text { krasszán }\end{array}$} & $\begin{array}{l}\text { primary fruit set (\%) after } \\
\text { petal fall }\end{array}$ & $9.9 \pm 2.4$ & $20.1 \pm 2.0$ & $9.6 \pm 3.5$ & $11.7 \pm 1.3$ & $7.3 \pm 2.9$ & $9.9 \pm 3.3$ & $2.9 \pm 1.3$ \\
\hline & number of fruits at harvest time & $1.0 \pm 0.7$ & $0.5 \pm 0.5$ & $1.3 \pm 0.7$ & 0 & 0 & 0 & 0 \\
\hline & $\begin{array}{l}\text { mass of fruits (yield) from } \\
50 \text { flowers }(\mathrm{g})\end{array}$ & $140.0 \pm 100.6$ & $72.1 \pm 72.1$ & $200.8 \pm 116.9$ & 0 & 0 & 0 & 0 \\
\hline
\end{tabular}

Table 3. Yield of pear cultivars as affected by reduced bee pollination period

\begin{tabular}{|c|c|c|c|c|c|c|c|}
\hline \multirow[b]{2}{*}{ Cultivar } & \multicolumn{7}{|c|}{ Relative yield (mass of fruits is per cents) as compared to the mean values of all treatments for individual cultivars } \\
\hline & $\begin{array}{c}\mathbf{1 0 0 \%} \text { open } \\
\text { (free pollination) }\end{array}$ & $\begin{array}{c}\text { 67\% open first } \\
\text { (caged in the last } \\
1 / 3 \text { of } \\
\text { the flowering) }\end{array}$ & $\begin{array}{l}\text { 67\% open last } \\
\text { (caged in the } \\
\text { first } 1 / 3 \text { of } \\
\text { the flowering) }\end{array}$ & $\begin{array}{l}\text { 50\% open first } \\
\text { (caged in } \\
\text { the second } \\
\text { half of } \\
\text { the flowering) }\end{array}$ & \begin{tabular}{|} 
50\% open second \\
(caged in the first \\
half of \\
the flowering)
\end{tabular} & $\begin{array}{l}\text { 33\% open first } \\
\text { (open in } \\
\text { the first } 1 / 3 \text { of } \\
\text { the flowering) }\end{array}$ & $\begin{array}{c}\text { 0\% open } \\
\text { (caged during } \\
\text { the whole } \\
\text { flowering } \\
\text { period) }\end{array}$ \\
\hline \multicolumn{8}{|l|}{ Győr 2007} \\
\hline Peckham's triumph & 236 & 173 & 90 & 67 & 25 & 97 & 11 \\
\hline Beurrée Bosc & 165 & 294 & 146 & 0 & 0 & 95 & 0 \\
\hline \multicolumn{8}{|l|}{ Bartlett } \\
\hline (Vilmos) & 260 & 53 & 6 & 187 & 25 & 113 & 0 \\
\hline \multicolumn{8}{|c|}{ Mosonmagyaróvár 2008} \\
\hline Hóka & 121 & 19 & 108 & 231 & 55 & 55 & 59 \\
\hline Beurrée Hardy & 328 & 15 & 78 & 125 & 0 & 130 & 25 \\
\hline Peckham's triumph & 70 & 78 & 111 & 314 & 13 & 87 & 27 \\
\hline Téli esperes & 294 & 119 & 70 & 104 & 51 & 0 & 65 \\
\hline \multicolumn{8}{|l|}{ Pisroska } \\
\hline & 209 & 38 & 116 & 0 & 157 & 116 & 64 \\
\hline Szücsi körte & 190 & 201 & 0 & 0 & 138 & 173 & 0 \\
\hline \multicolumn{8}{|l|}{ Clapp's favourite } \\
\hline & 221 & 93 & 202 & 82 & 63 & 40 & 0 \\
\hline Mézes körte & 119 & 206 & 214 & 113 & 49 & 0 & 0 \\
\hline Olivier de Serres & 254 & 148 & 297 & 0 & 0 & 0 & 0 \\
\hline Nemes krasszán & 237 & 122 & 340 & 0 & 0 & 0 & 0 \\
\hline
\end{tabular}

Table 4. Statistical reliability of the relationship between the effective bee pollination period and the relative yield of pear cultivars

\begin{tabular}{|l|l|c|c|c|c|}
\hline \multicolumn{1}{|c|}{ Experimental site } & \multicolumn{1}{|c|}{$\begin{array}{c}\text { Equation } \\
\mathrm{y}=\text { relative yield } \\
\mathrm{x}=\text { effective bee pollination period } \\
\text { (as the per cent of the flowering time) }\end{array}$} & $\begin{array}{c}\text { Regression } \\
\text { coefficient }\end{array}$ & Probability & Number of data & $\begin{array}{c}\text { Number of } \\
\text { cultivars tested }\end{array}$ \\
\hline Györ 2007 & $\mathrm{y}=2.0652 \mathrm{x}-8.4198$ & $\mathrm{r}=0.6714$ & $\mathrm{p}=95 \%$ & $\mathrm{n}=21$ & 3 \\
\hline Mosonmagyaróvár 2008 & $\mathrm{y}=1.8336 \mathrm{x}+3.2104$ & $\mathrm{r}=0.5643$ & $\mathrm{p}=95 \%$ & $\mathrm{n}=70$ & 10 \\
\hline Győr 2007 + Mosonmagyaróvár 2008 $\mathrm{y}=1.887 \mathrm{x}+0.5265$ & $\mathrm{r}=0.5878$ & $\mathrm{p}=95 \%$ & $\mathrm{n}=91$ & 13 \\
\hline
\end{tabular}




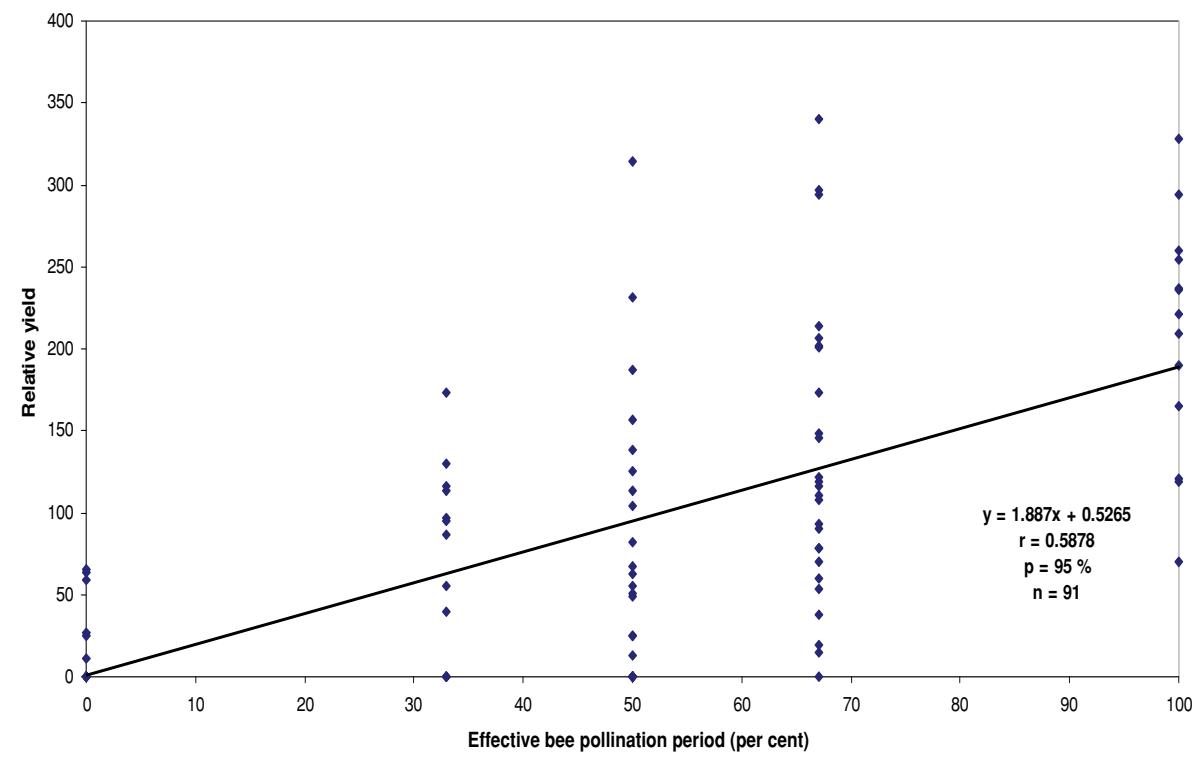

Figure 1. Yield of pear as a function of the effective bee pollination period: Györ 2007 + Mosonmagyaróvár 2008 (13 cultivars)
Nyéki et al. (1998) carried out detailed experiments to explore the parthenocarpic capacity of a great number of pear cultivars and they classified the tested cultivars into 6 categories ranging from no tendency to very strong expression of parthenocarpy. They supposed that parthenocarpic fruit formation can be induced by adverse conditions, among others when bee pollination is prevented from some reasons. Based on our experimental results, however, no definite relationship between parthenocarpic capacity of cultivars and the yield under reduced bee pollination can be established. So reduced bee pollination does not seem to contribute the parthenocarpic fruit formation in pear. pathenocarpous fruit set (category 3 of Nyéki et al., 1998) produced no yield at some instances and gave some minor yield at other cases when bee pollination was completely reduced.

\section{Discussion and conclusions}

Changing weather and sometimes the lack of sufficient number of bee colonies at the nearby can greatly limit the duration of the effective bee pollination period in flowering fruit plantations. Results of our experiments prove that pear is more or less sensitive to the reduced bee pollination period. However, the reaction (or the sensitivity) of cultivars may be different to the reduced bee pollination. Most cultivars produce much less yield under reduced bee pollination or no yield with the exclusion of bees but in the case of some cultivars total exclusion of bees does not prevent the yield formation and what is more sometimes reduced bee pollination can be resulted in somewhat higher yield than open pollination. Typical reaction, however, is a significant yield reduction with reduced bee pollination and this finding is in a good accordance with the literature (Free 1993).

Pear, on the other hand, seems to be somewhat less sensitive to the partial reduction of bee pollination period than apple or quince because the latter fruit species give much less or no yield even under partial limitation of bee pollination (Benedek et al., 1989, Benedek \& Nyéki 1995, 1996b, 1997, Benedek et al., 2000ab).

Interestingly, the first half of the flowering period seems to be more important in yield formation because usually higher yield was resulted when pear cultivars received open pollination in the first than in the second half of the blooming period. This finding corroborates our earlier statement (Benedek et al., 2000ab).

\section{References}

Benedek P., Nyéki J. (1995): Role of bee pollination in the fruit set and yield of self-fertile and self-sterile apple, sour cherry and plum cultivars. Horticultural Science, 27: (3-4): 34-37.

Benedek P., Nyéki J. (1996a): Fruit set of selected self-sterile and self-fertile fruit cultivars as affected by the duration of insect pollination. Acta Horticulturae, 423: 57-63.

Benedek P., Nyéki J. (1996b): Relationship between the duration of insect pollination and the yield of some apple cultivars. Horticultural Science, 2(3-4): 93-96.

Benedek P., Nyéki J. (1997): Yield of selected apple cultivars as affected by the duration of bee pollination. Acta Horticulturae, 437: 207-211.

Benedek P., Nyéki J., Lukács Gy. (1989): A méhmegporzás intenzitásának hatása az alma kötődésére és termésére. Kertgazdaság, 21 (3): 8-26.

Benedek P., Nyéki J., Soltész M., Erdős Z., Skola I., Szabó T., Amtmann I., Bakcsa F., Kocsisné Molnár G., Vadas Z., Szabó Z. (2000a): The effect of the limitation of insect pollination period on the fruit set and yield of temperate-zone fruit tree species. Internat. J. Horticult. Science, 6 (1): 91-95.

Benedek P., Szabó T., Nyéki, J. (2000b): The effect of the limitation of insect pollination period on the fruit set and yield of quince cultivars (Cydonia oblonga Mill.). Internat. J. Horticultural Science, 6 (3): 103-108.

Free, J. B. (1993): Insect pollination of crops. Second enlarged edition. Acad. Press, London

Nyéki, J., Soltész M. (1996): Floral biology of temperate zone fruit trees and small fruits. Akadémiai Kidó, Budapest: 377 pp.

Nyéki, J., Soltész M., Iváncsics J. (1998): Natural tendency to parthenocarpy of pear varieties in Hungary. Acta Horticulturae, 475: 367-377.

Roversi, A., Ughini, V. (1986): Ricerche sulla biologia fiorale del ciliego dolce. Ann. Fac. Agraria. U.C.S.C. (Piacenza), 26: 189-203. 